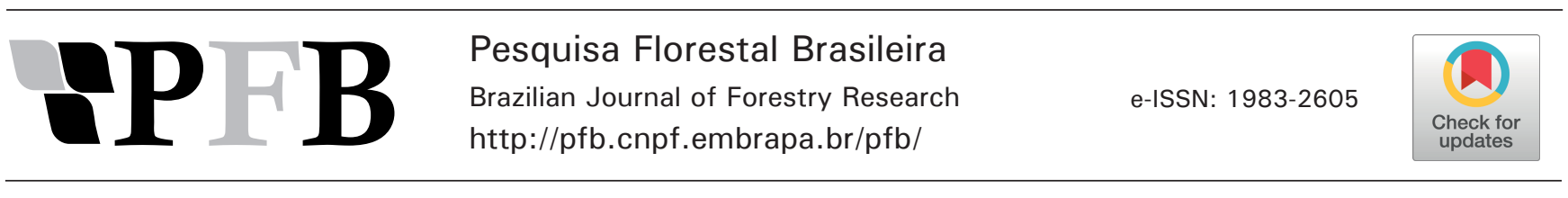

\title{
Seeds of Peltophorum dubium submitted to osmotic conditioning increases germination and vigor
}

\author{
Evandro Luiz Missio ${ }^{1 *(D)}$, Ubirajara Russi Nunes ${ }^{2}$ (D) , Cleber Witt Saldanha1(D), Joseila Maldaner ${ }^{1}$ (D), Gerusa Pauli Kist Steffen ${ }^{1}$ (D), \\ Rosana Matos de Morais ${ }^{1}$ (D)
}

${ }^{1}$ Centro de Pesquisa em Florestas, BR 287, Acesso VCR 830, Km 4,5, CEP 97001-970, Santa Maria, RS, Brasil

Universidade Federal de Santa Maria, Av. Roraima, N 1000, CEP 97105-900, Santa Maria, RS, Brasil

"Corresponding author:

evandro.missio@gmail.com

Index terms:

Osmopriming

Water potential

Seedling production

Termos para indexação:

Osmocondicionamento

Potencial hídrico

Produção de mudas

Received in 11/01/2018

Accepted in 04/09/2018

Published in 12/12/2018

doi: 10.4336/2018.pfb.38e201801561

\begin{abstract}
Peltophorum dubium (Spreng.) Taub. is a Brazilian native forest species that is used in programs of environmental restoration, landscaping and civil construction. It is a seed-propagated plant, but the low physiological quality of the seeds associated with biotic and abiotic stresses can reduce the percentages of germination and emergence. Techniques that allow the expression of the physiological potential of the seeds can improve germination and vigor in short-term. One of these techniques is seeds osmoconditioning, especially under stressful conditions. This work aimed to study if the osmopriming increases germination and vigor of $P$. dubium seeds. The study consisted of three stages: I - choice of the ideal osmotic potential for imbibition; II - germination and vigor of the osmoprimed seeds under different water contents; III - osmopriming of four seed lots with different vigor. PEG 6000 solution with $-0.6 \mathrm{MPa}$ is recommended for osmoconditioning of $P$. dubium seeds aiming to improve germination and vigor. Seeds with water content close to $10 \%$ for osmoconditioning influences the vigor positively. Osmoconditioning can improve physiological aspects of $P$ dubium seeds with good physiological quality. It can reduce germination-emergence time span, favoring stands with greater uniformity and lower probability of biotic and abiotic factors influence.
\end{abstract}

\section{Sementes de Peltophorum dubium submetidas ao condicionamento osmótico aumentam a germinação e vigor}

Resumo - Peltophorum dubium (Spreng.) Taub. é uma espécie florestal nativa do Brasil utilizada em programas de restauração ambiental, paisagismo e construção civil. Sua propagação ocorre de forma seminal, porém, problemas na qualidade fisiológica das sementes aliados a ação de fatores bióticos e abióticos podem reduzir os percentuais de germinação e emergência. Neste contexto, técnicas que permitam a expressão do potencial fisiológico das sementes podem melhorar a germinação e o vigor em menor espaço de tempo. Uma destas técnicas é o condicionamento osmótico das sementes, o qual visa proporcionar a germinação mais rápida e uniforme, especialmente sob condições de estresse. O objetivo deste trabalho foi estudar se o condicionamento osmótico aumenta a germinação e o vigor de sementes de P. dubium. O estudo constituiuse de três etapas: I - seleção do potencial osmótico ideal para a embebição; II - vigor e germinação de sementes osmocondicionadas e com diferentes teores de água; III osmocondicionamento de quatro lotes de sementes com diferenças no vigor. A solução de PEG 6000 com -0,6 MPa é recomendada para o condicionamento osmótico de sementes de $P$. dubium com o objetivo de melhorar a germinação e o vigor. Sementes com teor de água próximo a $10 \%$ para o condicionamento osmótico influenciam positivamente o vigor. O condicionamento osmótico pode melhorar os aspectos fisiológicos de sementes de $P$. dubium com boa qualidade fisiológica, podendo reduzir o tempo de germinação e emergência e favorecendo os talhões com maior uniformidade e menor probabilidade de influência dos fatores bióticos e abióticos. 


\section{Introduction}

Knowledge about the ecology of native forest species is of great importance when propagation for protection purposes, seedling supply for environmental restoration programs or logging is aimed.

Among forest species, Peltophorum dubium (Spreng.) Taub. stands out as having potential to fulfill such aim. This species is native to Brazil and the seedlings can be employed in landscapes systems, mixed reforestation composition, degraded areas, permanent preservation areas and its wood is useful for carpentry, energy and civil construction (Carvalho, 2003). Its propagation occurs predominantly by seeds that have a hard coat and good storage tolerance.

One of the main challenges in the propagation of forest species is related to seeds germination and vigor. Often, in the substrate, seeds experience an unfavorable environment for germination. In this case, it is desirable that seeds have a high physiological potential for quick and uniform emergence (Marcos Filho, 2005), so they are exposed for a shorter time to biotic and abiotic factors that can negatively affect germination (Sampaio et al., 2016). Studies of techniques that allow the expression of the physiological potential of the seeds play an important role to increase the percentage of emergence in a shorter time. One of these techniques is the osmoconditioning, also called osmotic priming or controlled pre-hydration of seeds.

Osmoconditioning is a technique that aims to promote faster and uniform germination, especially under stressful conditions (Heydecker et al., 1975). It is based on the controlled hydration of the seeds at a rate that allows activating the pre-germinative metabolic processes without radicle emission (Bradford, 1986). According to McDonald Junior et al. (1988), osmoconditioning makes up a feasible alternative to favor the increase in seed performance in the field, particularly under adverse conditions, mainly in lots with low physiological quality.

There is scientific information supporting that osmoconditioning promotes significant gains in seed germination and vigor of vegetables (Batista et al., 2015; Armondes et al., 2016) as well as germination, emergence and seedlings vigor of crops such as Glycine max (Silva et al., 2016b), Phaseolus vulgaris (Coelho et al., 2010; Masuthi et al., 2015) and Helianthus annuus (Rabbani et al., 2013).
In forest species, osmoconditioning of seeds has been reported in different studies with several species and focused on the optimization of the physiological potential. Increases in germination, emergence and/or seedling quality were observed with osmoconditioning in Bauhinia forficata (Duarte \& Nunes, 2010), Myracrodruon urundeuva (Cardoso et al., 2012; Virgens et al., 2012), Sesbania virgata (Masetto et al., 2013), Bixa orellana (Kissmann et al., 2013), Anadenanthera falcata (Mota et al., 2013), Stryphnodendron polyphyllum, S. adstringens (Scalon et al., 2014), Citrus volkameriana (Oliveira et al., 2014) and Eugenia stipitata (Silva et al., 2016a). These findings evidence the benefits of osmoconditioning and data obtained for the abovementioned species can aid the large-scale propagation aimed to supply seedlings with high quality for environmental restoration programs. However, there is another range of tree species, including $P$. dubium, for which such information of practical application is still missing.

This work aimed to study if the osmoconditioning increases germination and vigor of $P$. dubium seeds.

\section{Material and methods}

Samples from four lots of Peltophorum dubium lots were collected from matrices located in seed sampling area (SSA) of Fepagro Florestas (29 40'04'S; $\left.53^{\circ} 54^{\prime} 01^{\prime \prime} \mathrm{W}\right)$, in the municipality of Santa Maria, Rio Grande do Sul State. After collected, the seeds were processed, dried in a greenhouse at ambience temperature $\left(15^{\circ} \mathrm{C}\right.$ to $\left.30^{\circ} \mathrm{C}\right)$ and stored (Kraft paper bag) in a dry cold chamber under controlled conditions of both temperature $\left(6^{\circ} \mathrm{C}\right.$ to $\left.9^{\circ} \mathrm{C}\right)$ and initial relative water content in the air (35\% to $60 \%)$. Initial physical and physiological characteristics of each lot are described in Table 1.

The work comprised three stages: determination of the osmotic potential for seed imbibition; germination and vigor of osmoconditioned seeds with different water contents; and osmoconditioning of four seed lots with differences in vigor. In stages I and II, only the lot with the highest vigor (25/2015) obtained by submitting seeds to the electrical conductivity test (Table 1) described by Krzyzanowski et al. (1999) was used. In all stages, tegument dormancy of the seeds was overcome by cutting the opposite side to the micropile (Carvalho, 2003). 
Table 1. Initial water content, purity, thousand seed weight (TSW), germination and electrical conductivity of four seed lots of Peltophorum dubium stored in a dry cold chamber of Fepagro Florestas.

\begin{tabular}{|c|c|c|c|c|c|}
\hline Lot & $\begin{array}{c}\text { Water content } \\
(\%)\end{array}$ & Purity (\%) & $\begin{array}{l}\text { TSW } \\
(\mathrm{g})^{*}\end{array}$ & $\begin{array}{c}\text { Germination } \\
(\%)\end{array}$ & $\begin{array}{l}\text { Electrical conductivity } \\
\left(\mu \mathrm{S} \cdot \mathrm{cm}^{-1} \cdot \mathrm{g}^{-1}\right)^{* *}\end{array}$ \\
\hline $39 / 10$ & 10.30 & 99 & 26.64 & 52 & 47.33 \\
\hline $33 / 12$ & 11.10 & 99 & 55.01 & 87 & 32.38 \\
\hline $21 / 14$ & 15.76 & 99 & 41.00 & 71 & 42.38 \\
\hline $25 / 15$ & 10.24 & 99 & 57.71 & 92 & 32.10 \\
\hline
\end{tabular}

\section{Stage I - Determination of ideal osmotic potential for seed imbibition}

The study consisted of a factorial arrangement $(5 \mathrm{x}$ 8) involving five osmotic potentials $(0,-0.2,-0.4,-0.6$ and $-0.8 \mathrm{MPa})$ and eight imbibition times $(0,2,4,8,12$, 24, 48 and $72 \mathrm{~h}$ ) in completely randomized design with four replications. Polyethylene glycol (PEG-6000) was used to calculate the amount of salt for germination at the temperature of $25^{\circ} \mathrm{C}$ according to Villela et al. (1991). Salt was added to a pre-defined volume of deionized water and diluted with a magnetic stirrer.

Each replication, containing 50 seeds, was wrapped in four sheets of Germitest ${ }^{\circledR}$ paper and placed in Gerbox ${ }^{\circledR}$ boxes. The paper was cut previously based on the box size. Each Gerbox ${ }^{\circledR}$ received 30 mL of PEG-6000 solution, volume estimated to cover $30 \%$ of the seed. After setting up treatments, the boxes were placed in a B.O.D. chamber $\left(25 \pm 1{ }^{\circ} \mathrm{C}\right)$, where they remained until the end of the experiment. Seed imbibition was monitored by verifying water content after $0,2,4,8$, 12, 24, 48 and $72 \mathrm{~h}$. At each time, seeds were removed and weighed in a precision balance, and immediately brought back to the chamber. Seeds that were germinated or contaminated with plant pathogenic microorganisms were discarded during weighing.

\section{Stage II - Germination and vigor of seeds with different water contents submitted to osmoconditioning}

An experiment with the lot 25/2015 was carried out aiming to compare different initial seed water content associated with the best osmotic potential obtained in stage I. Experimental design was completely randomized with four replications of 50 seeds, in which four seed water contents were assessed $(6,10,14$ and 18\%).

Seeds were separated into four groups in order to have the proper initial water content. Seeds that required drying were placed in a forced air circulation oven at room temperature to reach the targeted water content. The lot $25 / 2015$ showed $10 \%$ of initial water content, that is, seeds needed to be dried only for the treatment with $6 \%$ of water content. For treatments that seeds needed to be hydrated (14 and 18\%), propagules were placed in a moisture chamber and weighed up to reach the desired value. Next, seeds were placed in Gerbox ${ }^{\circledR}$ boxes, with four sheets of Germitest ${ }^{\circledR}$ paper, followed by adding $30 \mathrm{~mL}$ of the best osmotic concentration of PEG 6000 obtained in stage I (-0.6 MPa). After establishing treatments, boxes were taken to a B.O.D. chamber $(25$ $\pm 1{ }^{\circ} \mathrm{C}$ ), where they remained for a pre-defined time. After the pre-imbibition period, seeds were washed with distilled water to remove the excess solution, placed on a Germitest ${ }^{\circledR}$ paper towel roll, and brought back to the chamber, where they remained until the period of data collection.

\section{Stage III - Osmoconditioning of four seed lots with different vigor}

Two experiments (greenhouse and laboratory) were conducted in factorial $(4 \times 2)$ completely randomized design, comparing four seed lots (39/10, 33/12, 21/14 and 25/15) and osmoconditioning (PEG, control) with four replications, totaling eight treatments. Osmotic potential and initial water content obtained in stages I and II were used. Seeds were placed in Gerbox ${ }^{\circledR}$ boxes, with four sheets of Germitest ${ }^{\circledR}$ paper followed by addition of $30 \mathrm{~mL}$ PEG 6000 and then taken to a B.O.D. chamber, where they remained for a pre-defined time. Afterwards, seeds were removed from the Gerboxes, and washed with distilled water to remove excess PEG solution.

In the laboratory, seeds were placed on a Germitest ${ }^{\circledR}$ paper towel roll after they were washed and then taken to a B.O.D. chamber $\left(25 \pm 1{ }^{\circ} \mathrm{C}\right)$, where they remained during the period of data collection. In the greenhouse, the seeds were sown on Gerbox ${ }^{\circledR}$ boxes containing Vermiculite $^{\circledR}$ substrate, and they were maintained under 
controlled temperature and initial water content during the evaluation time.

It was established the criterion of radicle emission ( $2 \mathrm{~cm}$ or more) for germination, and emission of cotyledons for emergence.

\section{Imbibition and sanity}

Unit weight of imbibed seeds - After incubation, seeds were weighed at $0,2,4,8,12,24,48$ and $72 \mathrm{~h}$. The results obtained for total weight were divided by the number of seeds, which allowed estimating the weight gain for each seed.

Sanity - Parallel to seed weight determination, seeds were scored for percentage of fungal incidence during incubation at different PEG concentrations. The rating scale varied from zero to five, in which zero comprised seeds that did not show any fungal growth and five was seeds that presented their entire surface covered by fungi.

\section{Germination}

Cumulative germination - It was performed at 7 and 14 days after incubation (Brasil, 2013). Results were expressed as percentage of germinated seedlings.

\section{Vigor}

Germination velocity index (GVI) - It was based on daily records of the number of germinated seedlings up to seven days after incubation. After finishing readings, GVI was calculated according to equation 1.

$$
\mathrm{GVI}=\mathrm{G} 1 / \mathrm{N} 1+\mathrm{G} 2 / \mathrm{N} 2+\ldots \mathrm{Gn} / \mathrm{Nn}
$$

Where: GVI = emergence velocity index; G1, G2, . Gn = number of normal seedlings computed at first, second and last count; $\mathrm{N} 1, \mathrm{~N} 2, \ldots \mathrm{Nn}=$ number of days from sowing to first, second and last count (Maguire, 1962).

Emergence velocity index (EVI) - It was calculated based on daily records of emerged seedlings up to 10 days after sowing. After finishing readings, EVI was calculated according to Equatio 2.

$$
\mathrm{EVI}=\mathrm{E} 1 / \mathrm{N} 1+\mathrm{E} 2 / \mathrm{N} 2+\ldots \mathrm{En} / \mathrm{Nn}
$$

Where: $\mathrm{EVI}=$ emergence velocity index; E1, E2, $\ldots$ En = number of normal plants that were computed at the first, second and last count; $\mathrm{N} 1, \mathrm{~N} 2, \ldots \mathrm{Nn}=$ number of days from sowing to the first, second and last count (Maguire, 1962).

First germination count - It was performed together with the first cumulative germination assessment. In this test, seedlings considered normal were counted and withdrawn. They were considered more vigorous because they germinated faster (Brasil, 2013).

First emergence count - It was performed together with the first cumulative emergence assessment. In this test, seedlings considered normal were counted and withdrawn. They were considered more vigorous because they emerged faster (Brasil, 2013).

Cumulative emergence - It was performed at 7 and 14 days after sowing (Brasil, 2013). Results were expressed as percentage of emerged seedlings.

After collected, data were submitted to Shapiro-Wilk's normality test, variance analysis and test of means or regression analysis. For all statistical procedures we usede the software Sisvar 5.4 (Ferreira, 2011).

\section{Results}

Results obtained from assessment of physiological potential of the four studied lots in stage I are shown in Figure 1. There was an increase in the weight of Peltophorum dubium seeds across imbibition times and water potentials (Figure 1a). Between 2 and $24 \mathrm{~h}$, there was a linear decrease in the seed weight as water potential became more negative. From $48 \mathrm{~h}$ onwards, the regression line became quadratic and negative, with values of weight decreasing up to $-0.6 \mathrm{MPa}$ and then increasing at $-0.8 \mathrm{MPa}$. Expect for 48 and $72 \mathrm{~h}$, seed weight showed an expected behavior that is gradually decreasing water uptake when exposed to more negative water potentials.

Germination of $P$. dubium seeds (Figure $1 \mathrm{~b}$ ) began at $24 \mathrm{~h}$ showing higher percentages in the treatment without PEG application, decreasing linearly as the water potential became more negative, reaching values close to zero in the treatment with $-0.8 \mathrm{MPa}$.

We observed an increase in microorganism multiplication on the seeds as water uptake was delayed by decreasing water potential (Figure 1c).

The initial seed water content (Stage II) significantly influenced germination and vigor (Table 2) when treatments were submitted to osmotic solution at -0.6 MPa for $24 \mathrm{~h}$ of controlled imbibition.

The GVI was higher in seeds that showed initial water content of $6 \%$ and it was not significantly different from the treatment with $10 \%$ of initial water content. In both treatments, seeds germinated quicker when they were exposed to the osmoconditioning. Seeds with 14 and $18 \%$ of initial water content showed lower germination velocity, statistically lower than seeds with $6 \%$ of initial 
water content. The same trend was observed for the first germination count, with seeds with initial water content between 6 and $10 \%$ showing higher vigor, as evidenced by the higher percentage of germinated seedlings, which resulted in values that were significantly higher relative to the treatments with 14 and $18 \%$ of initial water content.
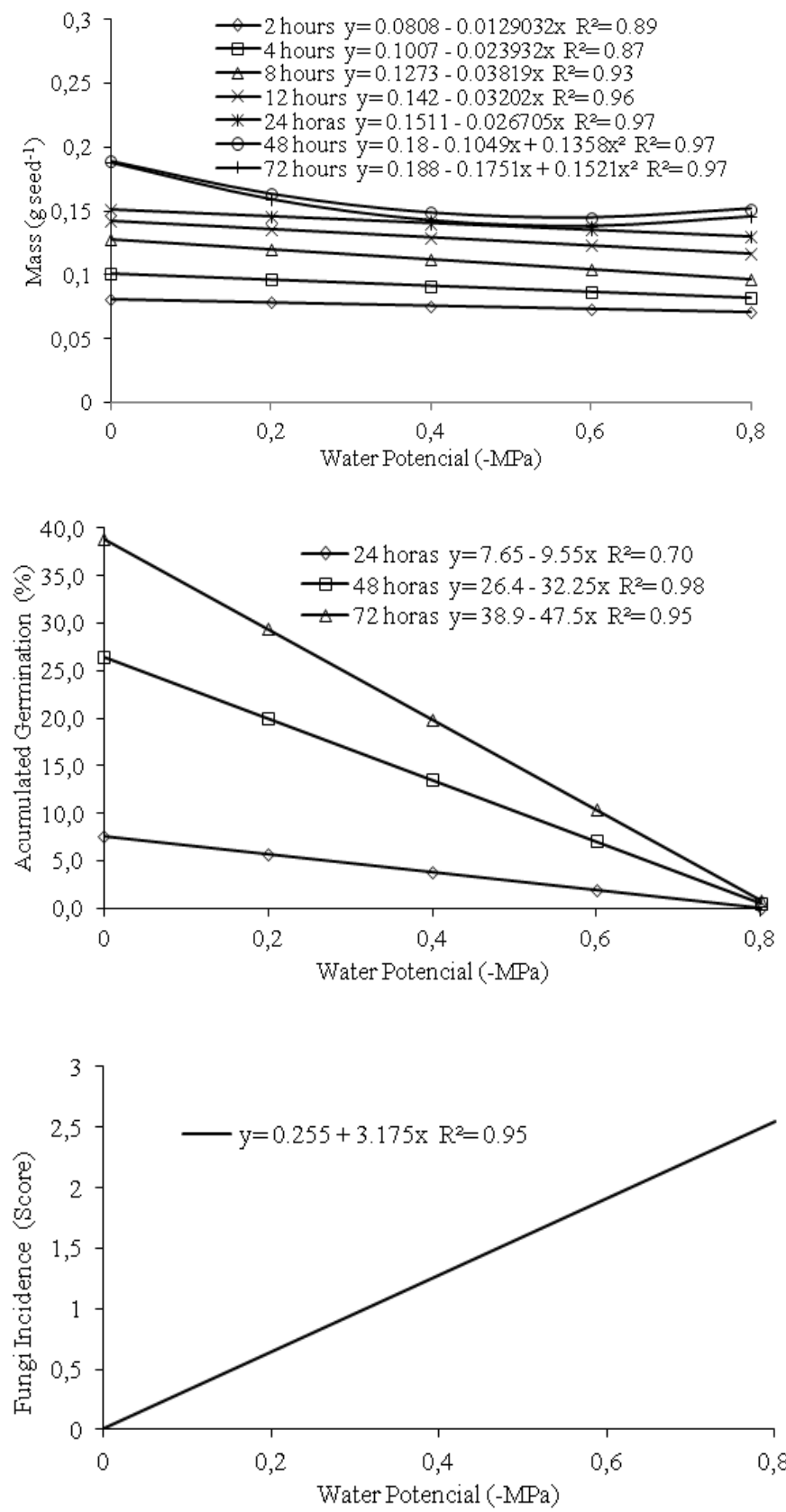

Figure 1. Weight (a), cumulative germination (b) and fungi incidence (c) in Peltophorum dubium seeds submitted to different water potentials and imbibition times.
Table 2. Germination velocity index (GVI), first germination count (FGC), cumulative germination (CG) and cumulative dead seeds (CD) of Peltophorum dubium seeds with different initial water contents and pre-conditioning during $24 \mathrm{~h}$ with PEG 6000 solution at $-0.6 \mathrm{MPa}$.

\begin{tabular}{ccccc}
\hline $\begin{array}{c}\text { Initial water } \\
\text { content } \\
(\%)\end{array}$ & $\begin{array}{c}\text { GVI } \\
\text { (seedlings day }^{-1} \text { ) }\end{array}$ & $\begin{array}{c}\text { FGC } \\
(\%)\end{array}$ & $\begin{array}{c}\text { CG } \\
(\%)\end{array}$ & $\begin{array}{c}\text { CD } \\
(\%)\end{array}$ \\
\hline 6 & $34.0 \mathrm{a}^{*}$ & $86.0 \mathrm{a}$ & $86.0 \mathrm{a}$ & $14.0 \mathrm{~b}$ \\
10 & $29.0 \mathrm{ab}$ & $84.0 \mathrm{a}$ & $84.0 \mathrm{a}$ & $16.0 \mathrm{~b}$ \\
14 & $28.0 \mathrm{~b}$ & $74.0 \mathrm{~b}$ & $74.0 \mathrm{~b}$ & $26.0 \mathrm{a}$ \\
18 & $28.0 \mathrm{~b}$ & $78.0 \mathrm{~b}$ & $78.0 \mathrm{~b}$ & $22.0 \mathrm{a}$ \\
\hline Mean & 30.0 & 80.4 & 80.4 & 19.5 \\
CV (\%) & 9.2 & 2.8 & 2.8 & 11.6 \\
\hline
\end{tabular}

Means followed by the same letter in the columns are not significantly different based on Tukey's test at 5\%.

The GVI was higher in seeds that showed $6 \%$ of initial water content and it was not significantly different from the treatment with $10 \%$ of initial water content. In both treatments, seeds germinated quicker when they were exposed to the osmoconditioning. Seeds with $14 \%$ and $18 \%$ of initial water content showed lower germination velocity, being statistically lower than seeds with $6 \%$ of initial water content. The same trend was observed for the first germination count, with seeds having initial water content between $6 \%$ and $10 \%$ showing higher vigor, as evidenced by the higher percentage of germinated seedlings, which resulted in values that were significantly higher when compared to the treatments with $14 \%$ and $18 \%$ of initial water content.

The two lowest initial seed water contents resulted in higher percentage of germination and lower percentage of dead seeds. Initial water contents of $14 \%$ and $18 \%$ resulted in percentage of germinated and dead seeds that were significantly lower and higher, respectively.

The results of comparison of seed lots of $P$. dubium with differences in vigor (Table 1) are presented in Table 3 (laboratory) and Table 4 (nursery).

There was significant interaction between preconditioning for all variables under study (Table 3).

Seed osmoconditioning resulted in higher germination velocity index (GVI) for all lots when compared to the non-osmoconditioned control, with germination gains (seedlings day $^{-1}$ ) of 3.9 (lot 39/10), 4.4 (lot 33/12), $1.9(\operatorname{lot} 21 / 14)$ and $3.2(\operatorname{lot} 25 / 15)$ relative to their counterparts without pre-conditioning, highlighted for the lot 39/10, which showed the lowest vigor (Table 1) and obtained the highest GVI gain, evidencing that conditioning allowed a vigor recovering of the seeds 
in laboratory conditions. It also should be noted the increase in GVI of the lot 25/15, which was the most vigorous, and even though showed a higher performance because of pre-conditioning.

Table 3. Germination velocity index (GVI), first germination count (FGC) and cumulative germination (CG) of seeds from four lots of Peltophorum dubium in the laboratory submitted or not to pre-conditioning.

\begin{tabular}{|c|c|c|}
\hline \multirow[t]{3}{*}{ Lot } & \multicolumn{2}{|c|}{ Pre-conditioning } \\
\hline & Control & Pre-conditioning ${ }^{(1)}$ \\
\hline & \multicolumn{2}{|c|}{ GVI (seedlings day ${ }^{-1}$ ) } \\
\hline $39 / 10$ & $3.4 \mathrm{Bb}^{*}$ & $7.4 \mathrm{Ab}$ \\
\hline $33 / 12$ & $4.3 \mathrm{Bb}$ & $8.7 \mathrm{Ab}$ \\
\hline $21 / 14$ & 8.0Aa & 10.0Aab \\
\hline $25 / 15$ & $9.3 \mathrm{Ba}$ & $12.6 \mathrm{Aa}$ \\
\hline Mean & 8.0 & \\
\hline \multirow[t]{2}{*}{ CV (\%) } & 22.9 & \\
\hline & \multicolumn{2}{|c|}{ FGC (\%) } \\
\hline $39 / 10$ & $35.0 \mathrm{Bc}$ & $64.0 \mathrm{Ab}$ \\
\hline $33 / 12$ & $44.0 \mathrm{Bbc}$ & 82.0Aab \\
\hline $21 / 14$ & 74.0Aab & 82.0Aab \\
\hline $25 / 15$ & 86.0Aa & $100 \mathrm{Aa}$ \\
\hline Mean & 70.8 & \\
\hline \multirow[t]{2}{*}{ CV (\%) } & 23.4 & \\
\hline & \multicolumn{2}{|c|}{ CG (\%) } \\
\hline $39 / 10$ & $35.0 \mathrm{Bc}$ & $66.0 \mathrm{Ab}$ \\
\hline $33 / 12$ & $44.0 \mathrm{Bbc}$ & 82.0Aab \\
\hline $21 / 14$ & 74.0Aab & 82.0Aab \\
\hline $25 / 15$ & $86.0 \mathrm{Aa}$ & 100Aa \\
\hline Mean & 70.8 & \\
\hline CV (\%) & 21.7 & \\
\hline
\end{tabular}

*Means that are followed by the same uppercase in the rows and lowercase in the columns are not significantly different based on Tukey's test at $5 \%$; ${ }^{(1)}$ Pre-conditioning during $24 \mathrm{~h}$ in a PEG 6000 solution at $-0.6 \mathrm{MPa}$ and seeds with water content adjusted to $10 \%$. CV $=$ coefficient of variation.

The first germination count (FGC) and cumulative germination (CG) followed the same trend of GVI, and at seven days, when first count was performed, seeds presented final results of germination. The lot 25/15 showed the highest percentage of germinated seeds for both non-pre-conditioned and pre-conditioned seeds (Table 3). The comparison among lots according to the conditioning showed that percentages that were significantly higher occurred for all lots that were preconditioned when compared to their non-pre-conditioned counterparts, but those lots with lower vigor showed the higher increases in FGC and CG, obtaining increases of
$29 \%(39 / 10)$ and $48 \%$ (33/12) in germination, confirming that the pre-conditioning positively influenced seeds with lower physiological quality.

The variables of vigor that were collected in nursery showed significant differences for lot and preconditioning (Table 4).

Table 4. Emergence velocity index (EVI), first emergence count (FEC) and cumulative emergence (CE) of seeds from four lots of Peltophorum dubium seeds submitted or not to the pre-conditioning in greenhouse.

\begin{tabular}{|c|c|c|}
\hline \multirow[t]{3}{*}{ Lot } & \multicolumn{2}{|c|}{ Pre-conditioning } \\
\hline & Control & Pre-conditioned $^{(1)}$ \\
\hline & \multicolumn{2}{|c|}{ EVI (seedlings day ${ }^{-1}$ ) } \\
\hline $39 / 10$ & $0.1 \mathrm{Bb}^{*}$ & $1.7 \mathrm{Ab}$ \\
\hline $33 / 12$ & $0.2 \mathrm{Ab}$ & $1.1 \mathrm{Ab}$ \\
\hline $21 / 14$ & $0.5 \mathrm{Bb}$ & $2.2 \mathrm{Ab}$ \\
\hline $25 / 15$ & $2.5 \mathrm{Ba}$ & $4.8 \mathrm{Aa}$ \\
\hline Mean & 1.6 & \\
\hline \multirow[t]{2}{*}{ CV $(\%)$} & 37.6 & \\
\hline & \multicolumn{2}{|c|}{ FEC (\%) } \\
\hline $39 / 10$ & $2.8 \mathrm{Bb}$ & $30.0 \mathrm{Ab}$ \\
\hline $33 / 12$ & $5.0 \mathrm{Bb}$ & $20.0 \mathrm{Ab}$ \\
\hline $21 / 14$ & $10.7 \mathrm{Bb}$ & $38.5 \mathrm{Ab}$ \\
\hline $25 / 15$ & $46.2 \mathrm{Ba}$ & 75.7Aa \\
\hline Mean & 28.6 & \\
\hline \multirow[t]{2}{*}{ CV (\%) } & 27.5 & \\
\hline & \multicolumn{2}{|c|}{ EA $(\%)$} \\
\hline $39 / 10$ & $37.1 \mathrm{Ab}$ & $35.0 \mathrm{Ab}$ \\
\hline $33 / 12$ & $41.4 \mathrm{Ab}$ & $32.8 \mathrm{Ab}$ \\
\hline $21 / 14$ & $49.2 \mathrm{Ab}$ & $47.1 \mathrm{Ab}$ \\
\hline $25 / 15$ & $67.8 \mathrm{Ba}$ & $100 \mathrm{Aa}$ \\
\hline Mean & 51.3 & \\
\hline CV (\%) & 17.9 & \\
\hline
\end{tabular}

*Means that are followed by the same uppercase in the rows and lowercase in the columns are not significantly different based on Tukey's teste at 5\%; (1) Pre-conditioned during $24 \mathrm{~h}$ in a PEG 6000 solution at $-0.6 \mathrm{MPa}$ and seeds with water content adjusted to $10 \%$. CV $=$ coefficient of variation.

The remaining lot presentend (33/12) an emergence velocity index (EVI) significantly higher when seeds were pre-conditioned. As it was observed in the laboratory, the lot 25/15 showed the highest EVI for both non-pre-conditioned and conditioned seeds. When it was pre-conditioned, the lot $25 / 15$ presented emergence significantly higher by 2.4 seedlings day $^{-1}$ compared to the control. The lots $21 / 14$ and $39 / 10$ that were pre-conditioned also presented EVI with 1.7 and 1.6 more seedlings day ${ }^{-1}$ than seeds without conditioning, 
indicating that the controlled pre-imbibition in the osmotic solution recovered seeds vigor.

Osmoconditioning increased the percentage of emerged seedlings in the first emergence count (FEC), remarkably for the lots $39 / 10(27.2 \%), 21 / 14(27.9 \%)$ and 21/15 (29.4\%). For both non-osmoconditioned and osmoconditioned seeds, the lot $25 / 15$ was significantly higher than the other lots (Table 4). However, this trend was not observed for the cumulative emergence (CE), for which only the lot 25/15 showed increases in the percentage, reaching $100 \%$ in the final count, with a significant increase of $32.2 \%$ compared to the non-preconditioned seeds. The other treatments did not differ significantly regarding the omoconditioning.

\section{Discussion}

In order to obtain the osmotic potential that allows germination phases I and II without radicle protrusion, and with low incidence of fungi, $24 \mathrm{~h}$ of seed exposure at $-0.6 \mathrm{MPa}$ was found to promote better conditions for the beginning of germination in a controlled environment. This information is based on the low percentage of germination that was obtained (Figure 1b), but with satisfactory weight gain (Figure 1a) and low incidence of fungi on the seed surface (Figure 1c). Thus, a controlled hydration pattern can be set up for the species, which allows the reduction of damages by the abrupt entry of water into the seed, avoiding damages to the embryonic cell walls. Furthermore this allows the propagule to be taken to the substrate with stages I and II of the germination process carried out under controlled conditions.

This result is supported by the concept pointed out by Parera \& Cantliffe (1994) about osmoconditioning, in which seeds undergo controlled hydration after a time of imbibition, with occurrence of the germination phases I and II without emergence of the primary root (phase III). In Brassica oleracea seeds, Armondes et al. (2016) used a -1.0 MPa osmotic potential at $20^{\circ} \mathrm{C}$ in PEG solution for the physiological conditioning of the seeds. Silva et al. (2016b) employed the same potential when they worked with osmoconditioning of Glycine max seeds with the purpose to determine its influence in grain yield. For Citrus volkameriana seeds, water potentials between -0.6 MPa and -1.0 MPa were the most indicated in order to obtain high percentage of germination (Oliveira et al., 2014).
Information generated in stage II suggests that Peltophorum dubium seeds with water content of $10 \%$ can express their vigor when exposed to the osmoconditioning in PEG 6000 solution at $-0.6 \mathrm{MPa}$ for $24 \mathrm{~h}$. Although the best results in germination and vigor were found in the treatment with $6 \%$ of seed water content, the values were not significantly different from that of $10 \%$, which favors the choice of the later because most of the lots collected and environment-dried reach initial water contents close to $10 \%$. It is noteworthy that P. dubium seeds are considered to be orthodox, that is, they are tolerant to desiccation at low percentages of initial water content, being able to lose more than $90 \%$ of the water content without losing their viability (Ferreira \& Borguetti, 2004; Baskin \& Baskin, 2014).

When seed propagation is desired, the adequate water content in the seed is an important factor to be considered. According to Baskin \& Baskin (2014) the imbibition period is considered critical for the seed and can have a negative or positive influence in the germination process. Marcos Filho (2005) states that great differences between seed and substrate water potentials may result in a very quick entry of water into the seed, especially in the less vigorous seeds, promoting imbibition damages, that causes the release of large amounts of exudates and rupture of the cellular structure. In the present study, we observed that osmoconditioning allowed the lower percentages of water in the seeds, resulting in greater germination and vigor indexes that may be associated with the osmotic potential adjusted in stage I, which decreased the water uptake rate by the seed without any imbibition damage.

The results obtained in Table 3 show that, regardless of the physiological quality of the lots, the vigor expression was improved when the seeds were submitted to osmotic conditioning. The comparison of GVI among pre-conditioned lots showed that the most recent lot, collected in 2015, presented the highest GVI, being statistically similar to the lot of 2014 and higher than lots that were stored longer (33/12 and 39/10). These findings corroborate with the literature, in which it is mentioned that the efficiency of the physiological conditioning allows a greater expression of the physiological potential of the seeds through uniformity of the vigor of different lots, fact that was ascribed to the controlled hydration process of the seeds, in which phases I and II of the germination process occur (Marcos Filho, 2005). Similar results were also found in E. stipitata, for which 
osmoconditioning increased germination velocity (Silva et al., 2016a). In $S$. virgata seeds, there was also an increase in the germination and GVI after seeds were osmoconditioned (Masetto et al., 2013).

The first germination count (FGC) and cumulative germination (CG) (Table 3) presented similar behavior as by found Bittencourt et al. (2005), who observed that osmoconditioning increased the percentage of germination of Asparagus officinalis seeds with low physiological quality. The lot $25 / 15$, though it was not significantly different when compared to the non-preconditioned treatment, showed an increase of $14 \%$ in germination, reaching $100 \%$ when seeds were preconditioned, which shows that osmoconditioning can be recommended. In Citrus volkameriana seeds, Oliveira et al. (2014) concluded that germination and GVI were influenced by osmoconditioning with potential from -0.6 MPa onwards.

The EVI results (Table 4) are in line with other studies that verified a positive influence of the osmoconditioning in the vigor of seed lots that had a poor physiological quality (Farooq et al., 2009). Considering the osmoconditioned seeds, the EVI of the lot $25 / 15$ (4.9) was almost twice higher than that of 21/14 and four times higher than the lot with the lowest EVI (33/12), which confirms that despite the high initial vigor, the physiological potential of the seeds can be better expressed when they are submitted to the osmoconditioning.

Osmoconditioning is a viable alternative to favor the increase in seed performance in the field, particularly under adverse conditions and in lots with low physiological quality (Tables 1 and 4) since once the potential is adjusted to the studied species, gains in germination and vigor can be obtained, also called vigor recovering of the seed.

The term vigor recovering, attributed to the increase in vigor of seeds with low physiological quality caused by the osmoconditioning of the seeds results from the adjustment of the seed potential and external medium in the period of seed imbibition. Imbibition is considered critical in the germination process of the seeds and can influence it positively or negatively because, depending on seed water content, the nature of plasma membrane varies (Vertucci, 1989). Seeds that tolerate desiccation, including those from $P$. dubium, show changes in their cell membranes, causing that in the imbibition process water enters quickly due to the large difference between the water potential of the seed and substrate, without allowing that membranes have enough time for restructuring, resulting in imbibition damage (Ferreira \& Borguetti, 2004; Marcos Filho, 2005; Baskin \& Baskin, 2014). The controlled hydration of the seeds allows an adjustment of the potential of the seed and the external environment that makes the water absortion by seeds slower, thus avoiding or at least attenuating the damages to the seeds.

Results obtained in this work for P. dubium seeds allow the recommendation of this technique when largescale propagation is aimed. The osmotic potential of -0.6 $\mathrm{MPa}$ adjusted to the initial seed water content of $10 \%$ improved seeds germination and vigor (Tables 4 e 5). It is important to highlight that the vigor recovering process was not effective only for the lots with low initial vigor but also for those that showed high vigor (lot 25/15) and that was used in the stages I and II of this work.

\section{Conclusions}

PEG 6000 solution with -0.6 MPa is recommended for osmoconditioning of Peltophorum dubium seeds aiming to improve germination and vigor.

Seeds with water content close to $10 \%$ for osmoconditioning influences positively the vigor.

Osmoconditioning can improve physiological aspects of $P$. dubium seeds with good physiological quality. It can reduce germination-emergence time span, favoring stands with greater uniformity and lower probability of biotic and abiotic factors influence.

\section{References}

Armondes, K. A. P. et al. Condicionamento osmótico e desempenho de sementes de repolho com diferentes níveis de vigor. Horticultura Brasileira, v. 34, p. 428-434, 2016. DOI: 10.1590/S010205362016003020.

Baskin, C. C. \& Baskin, J. M. Seeds: ecology, biogeography, and evolution of dormancy and germination. Amsterdam: Academic Press, 2014. 1600 p.

Batista, T. B. et al. Aspectos fisiológicos e qualidade de mudas da pimenteira em resposta ao vigor e condicionamento das sementes. Bragantia, v. 74 , n. 4 , p. $367-373$, 2015. DOI: 10.1590/16784499.0133 .

Bittencourt, M. L. C. et al. Germination and vigour of primed asparagus seeds. Scientia Agricola, v. 62, n. 4, p. 319-324, 2005. 
Bradford, D. J. Manipulation of seed water relations via osmotic priming to improve germination under stress conditions. Hort Science, v. 21, p. 1105-12, 1986.

Brasil. Ministério da Agricultura, Pecuária e Abastecimento. Secretaria de Defesa Agropecuária. Instruções para análise de sementes de espécies florestais. Brasília, DF, 2013. 97 p.

Cardoso, N. S. et al. Osmocondicionamento na germinação de sementes, crescimento inicial e conteúdo de pigmentos de Myracrodruon urundeuva fr. Allemão. Revista Brasileira de Biociências, v. 10, n. 4, p. 457-461, 2012.

Carvalho, P. E. R. Espécies arbóreas brasileiras. Brasília, DF: Embrapa Informação Tecnológica; Colombo: Embrapa Florestas, 2003. v. 1.1039 p.

Coelho, D. L. M. C. et al. Estresse hídrico com diferentes osmóticos em sementes de feijão e expressão diferencial de proteínas durante a germinação. Acta Scientiarum, v. 32, n. 3, p. 491-499, 2010. DOI: 10.4025/actasciagron.v32i3.4694.

Duarte, D. M. \& Nunes, U. R. Crescimento inicial de mudas de Bauhinia forficata Link em diferentes substratos. Cerne, v. 18. n. 2, p. 327-334, 2010. DOI: 10.1590/S0104-77602012000200018.

Farooq, M. et al. Improving of drought tolerance in rice (Oryza sativa L.) by exogenous application of salicylic acid. Journal of Agronomy and Crop Science, v. 195, p. 237-246, 2009. DOI: 10.1111/j.1439037X.2009.00365.x.

Ferreira, A. G. \& Borghetti, F. Germinação: do básico ao aplicado. Porto Alegre: Artmed, 2004. 323 p.

Ferreira, D. F. Sisvar: a computer statistical analysis system. Ciência e Agrotecnologia, v. 35, n. 6, p. 1039-1042, 2011. DOI: 10.1590/ S1413-70542011000600001.

Heydecker, W. et al. Invigoration of seeds? Seed Science \& Technology, v. 3, p. 881-888, 1975.

Kissmann, C. et al. Condicionamento das sementes e sombreamento na emergência e no crescimento de plantas de Bixa orellana L. Revista de Ciências Agrárias, v. 36, n. 1, p. 48-56, 2013.

Krzyzanowski, F. C. et al. Vigor de sementes: conceitos e testes. Londrina: ABRATES, 1999. 218 p.

Maguire, J. D. Speed of germination-aid in selection and evaluation for seedling emergence and vigor. Crop Science, v. 2, n. 2, p. 176177, 1962.

Marcos Filho, J. Fisiologia de sementes de plantas cultivadas. Piracicaba: FEALQ, 2005. 495 p.

Masetto, T. E. et al. Condicionamento osmótico de sementes de Sesbania virgata (CAV.) PERS (Fabaceae). Cerne, v. 19, n. 4, p. 629-636, 2013. DOI: 10.1590/S0104-77602013000400013.
Masuthi, D. et al. Different priming treatments on germination and viability of cluster bean seeds. International Journal of Advanced Research, v. 3, n. 5, p. 108-111, 2015.

McDonald Junior, M. B. et al. Seed coat regulation of soybean imbibition. Crop Science, v. 28, p. 987-992, 1988. DOI: 10.2135/ cropsci1988.0011183X002800060025x.

Mota, L. H. S. et al. Efeito do condicionamento osmótico e sombreamento na germinação e no crescimento inicial das mudas de angico (Anadenanthera falcata Benth. Speg.). Revista Brasileira de Plantas Medicinais, v. 15, n. 4, p. 655-663, 2013.

Oliveira, A. S. et al. Condicionamento osmótico em sementes de limão 'Volkameriano' (Citrus volkameriana Tan. and Pasq.). Scientia Plena, v. 10, n. 9, p. 1-9, 2014.

Parera, C. \& Cantliffe, D. Presowing seed priming. Horticultural Reviews, v. 16, p. 109-139, 1994. DOI: 10.1002/9780470650561. ch4.

Rabbani, A. R. C. et al. Condicionamento osmótico em sementes de girassol (Helianthus annuus L.). Revista Científica UDO Agrícola, v. 13, n. 1, p. 50-55, 2013.

Sampaio, M. F. et al. Influência de diferentes substratos associados a métodos de superação de dormência na germinação e emergência de sementes de jatobá (Hymenaea courbaril L.). Revista Farociencia, v. 2, n. 1, p. 11-27, 2016.

Scalon, S. P. Q. et al. Condicionamento fisiológico e níveis de sombreamento em sementes de barbatimão (Stryphnodendron polyphyllum (Mart.) e Stryphnodendron adstringens (Mart.) Coville). Revista Árvore, v. 38, n. 1, p. 145-153, 2014. DOI: 10.1590/S010067622014000100014.

Silva, M. L. et al. Osmopriming duration in Araçá-boi seeds germination. Revista Agroambiente, v. 10, n. 1, p. 17-21, $2016 \mathrm{a}$. DOI: 10.18227/1982-8470ragro.v10i1.2808.

Silva, T. A. et al. Seed priming, yield components and yield of soybean. Ciência Rural, v. 46, n. 2, p. 227-232, 2016b. DOI: 10.1590/0103-8478cr20141736.

Vertucci, C. W. The kinetics of seed imbibition: controlling factors and relevance to seedling vigor. In: Stanwood, P. C. \& McDonald, M. B. (Ed.). Seed moisture. Madison, 1989. p. 93-115. (CSSA Special Publication, 14).

Villela, F. A. et al. Tabela de potencial osmótico em função da concentração de polietileno glicol 6000 e da temperatura. Pesquisa Agropecuária Brasileira, v. 26, n.11/12, p. 1957-1968, 1991.

Virgens, I. O. et al. Comportamento fisiológico de sementes de Myracrodruon urundeuva Fr. All. (Anacardiaceae) submetidas a fatores abióticos. Ciência Florestal, v. 22, n. 4, p. 681-692, 2012. DOI: $10.5902 / 198050987550$. 